\title{
The energy source for heat pumps with vertical heat exchangers
}

\author{
Piotr Rynkowski ${ }^{1, *}$ \\ Bialystok University of Technology, Faculty of Civil and Environmental Engineering, \\ 15-351 Białystok, ul. Wiejska 45A, Poland
}

\begin{abstract}
The paper presents the ground temperature analysis, heat flows and energy transferred from the soil massif by the vertical ground heat exchangers (VGHE). Three cases - with one, two and three vertical heat exchangers were compared. Their influences on the soil massif temperature in the heat exchangers area were shown. The mass flow and the temperature at the inlet and outlet side of the heat pump were measured in each circuit. Additional, the electricity consumption by the heat pump and energy supply to buffer vessel were measured. Finally, the Coefficient of Performance (COP) as a function of length of VGHE is shown for selected interval time.
\end{abstract}

\section{Introduction}

The geothermal energy is one of the most reliable and stable renewable energy resources in the world. Commercial application of the geothermal energy noticeably increases with various types of ground heat exchangers compatible with ground source heat pumps systems (GSHP). Ground heat exchanger (GHE) is one of the most important component for the effective utilization of geothermal energy [1]. Low temperature geothermal resources are ubiquitous and globally utilized. The U-loop vertical ground heat exchangers (VGHEs) are the most widely adapted and applied in the world. Compared the low-potential energy sources for heat pump, from performance and economical parameters of the air, horizontal and vertical GHE the maximum output can be achieved by VGHE technology [2]. Good stability characteristic is the main advantage of ground/water heat pumps. The major limitation of using VGHE is high investment cost and it is an important part of the total investment cost for a GSHP application.

Many researches have focused on the heat transfer performance of the VGHE. Many analytical and numerical models have been developed to simulate VGHE [3-8]. Different scientific analyses have been done to increase heat exchange between borehole and ground [9-10]. Vertical ground heat exchangers have a great energy-saving potential, but ground heat storage has not been fully developed yet [11]. This undesirable side effect is mainly due to difficulties in the design and analysis of GHE, which involves complex heat transfer calculations. Further research on the thermal process of VGHE is crucial.

\footnotetext{
${ }^{*}$ Corresponding author: p.rynkowski@pb.edu.pl
} 


\section{Development idea}

In engineering practice the VGHE is usually constructed by inserting high-density polyethylene (HDPE) U-tube in a vertical borehole to serve as the ground loop, which is referred to a single U-tube GHE. Boreholes depths usually varies from 40 to $100 \mathrm{~m}$. To $100 \mathrm{~m}$ depth the additional permission from the mining law is not required. The diameter of boreholes varies from 75 to $150 \mathrm{~mm}$. The borehole wall temperature and heat flux are very important parameters for engineering application.

Due to the relatively high investment costs, in relation to the total cost in small objects, it often leads to underestimation heat exchanger. The Thermal Response Test (TRT) is the best tool to determine thermal properties of the ground heat exchanger [12-16]. As a result, the thermal conductivity and borehole thermal resistance are obtained. Since it is not economical, for small heating systems the TR is not performed.

Only with a correct designed system, the heat can be considered as renewable energy. To determine the optimal number of U-tubes which maximizes the commercial and engineering benefits, cost and performance analyses of U-tube boreholes are crucial.

The goal of this study is:

- monitoring temperature values and analyse the disturbed ground temperature changes in the vicinity of the heat exchangers,

- monitoring the energy drawn from the ground massif by VGHE during the heating period,

- estimate the value of Coefficient of Performance (COP) for analysed intervals.

The goal of additional further verifications is to determine the specific heat flow from the ground massif by VGHE during the heating period and maximizing energy drawn from the ground, asses the regeneration capabilities of the ground massif natural energy in VGHE stagnation period, assess to store thermal energy from solar radiation, assess degree of energy dissipation and analyse the operating parameters of VGHE.

\section{Description of the GSHP system}

\subsection{GSHP system}

The paper reports experimental investigation conducted on the heating system based on the heat pump installed at Bialystok Technical University, Poland. The heating system consist of the heat pump, vertical ground heat exchangers, distribution pipelines and circulation pumps on the load and source sides. The core of the system is the heat pump with polyethylene Upipe vertical borehole heat exchangers (PE $40 \times 4 \mathrm{~mm}$ ) surrounded by bentonite filler. The power of heat pump equals $7,8 \mathrm{~kW}$ (nominal thermal power, COP 4.7 for $5 / 35^{\circ} \mathrm{C}$ ). The heat pump works with $300 \mathrm{dm}^{3}$ buffer vessel and $66 \mathrm{~m}^{2}$ underfloor heating system. The sketch of GSHP is presented in Fig. 1. The VGHEs of 70, 85 and $100 \mathrm{~m}$ deep were installed into three $100 \mathrm{~m}$ deep boreholes. The outer diameter of the borehole is $150 \mathrm{~mm}$. Three $100 \mathrm{~m}$ deep control boreholes with temperature sensors were added. Distance between each VGHE is $10 \mathrm{~m}$ (Fig. 2). For verifications the ground temperature profile 27 temperature sensors were installed in each boreholes. The sensors are located at 1, 2, 3, 4, 5, 6, 7, 8, 9, 10, 12.5, 15, $17.5,20,25,30,35,40,45,50,55,60,65,70,80,90$ and $100 \mathrm{~m}$ depth.

The undisturbed ground temperature were measured before launching the heating system in each boreholes. 


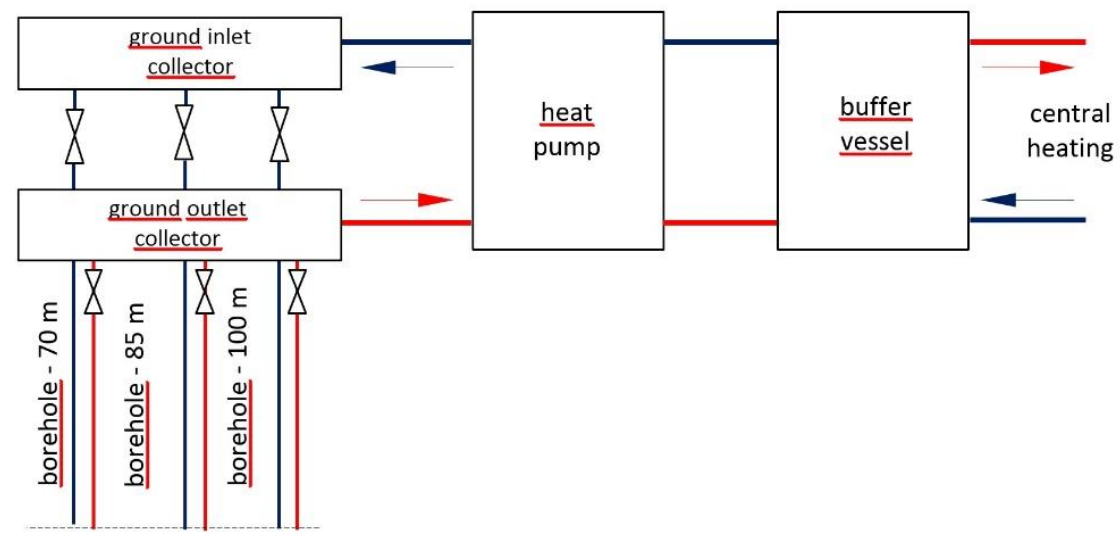

Fig. 1. The sketch of GSHP connected to three vertical ground heat exchangers.

\subsection{Data acquisition system}

The data acquisition system ran automatically by the control of computer. For VGHE performance monitoring system, the temperatures were measured by the DS18B20 digital thermometers $\left( \pm 0,5^{\circ} \mathrm{C}\right.$ accuracy). The digital thermometers were distributed at specific points, among others at inlet and outlet of the pipes. The flow rates of glycol/water was measured by water meter with pulse output Apator JS4-NK $( \pm 2.0 \%$ accuracy). The heat transferring agent is propylene glycol solution in water $\left(1038 \mathrm{~kg} / \mathrm{m}^{3}, 3.38 \mathrm{~kJ} /(\mathrm{kg} \cdot \mathrm{K})\right.$, concentration 39\%). The electricity consumption was measured by Acrel ADL 100 energy meter $( \pm 1.0 \%$ accuracy $)$.

\subsection{Experimental and measurement site}

The aim of the experiment was to monitor the temperature and analyse the disturbed ground temperature changes in the vicinity of the heat exchangers. By monitoring the energy drawn from the ground massif by VGHE during the heating period, it was possible to estimate the value of Coefficient of Performance (COP) for analysed intervals.

During the first part of the experiment the undisturbed ground temperatures were being measured in each borehole from October 2015 to September 2016.

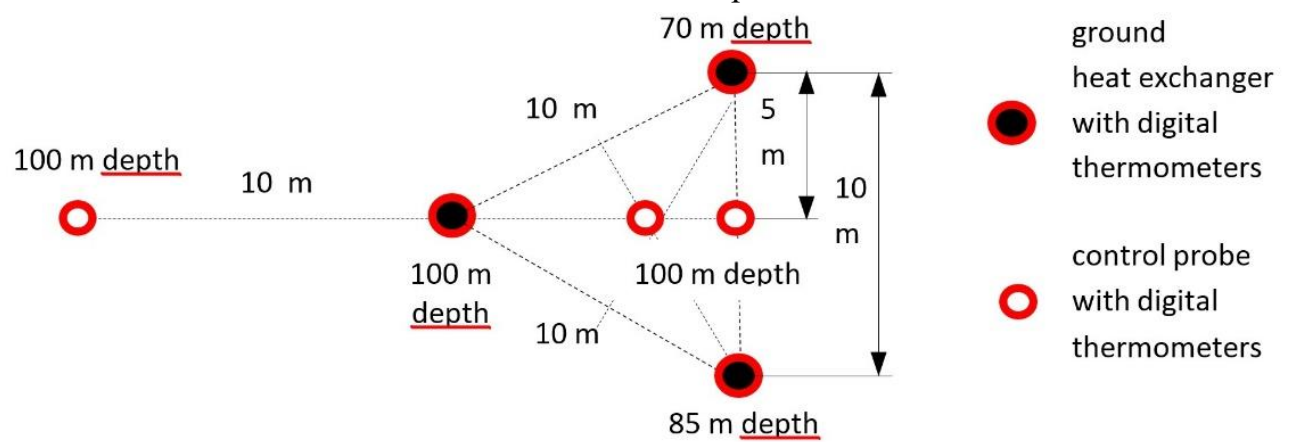

Fig. 2. Location the ground heat exchangers with control boreholes.

The stages of experiment were described in Table 1. The volumetric flow rates in source and in load side were measured. The electricity consumption of the heat pump and the 
circulating pumps were measured too. All measurements taken were recorded every five minutes.

Table 1. The heat pump work stages during the operating.

\begin{tabular}{|c|c|}
\hline Date & Process \\
\hline 12th Jan. 2017 - 16th Jan. 2017 & GSHP works with one GHE number 3 (100 m deep) \\
\hline 18th Jan. 2017 - 23th Jan. 2017 & GSHP works with two GHEs number 2 and 3 (85, 100 m deep) \\
\hline 25th Jan. 2017 - 30th Jan. 2017 & GSHP works with three GHE number 1, 2 and 3 \\
(70, 85 and 100 m deep)
\end{tabular}

The heat rate balance for a working fluid passing through one, two and three VGHE was calculated according to the following Eq. (1), where $m$ - mas flow rate, $\mathrm{kg} / \mathrm{s} ; c_{p}$ - specific heat, $\mathrm{J} /(\mathrm{kg} \cdot \mathrm{K}) ; T$ - temperature, respectively at inlet and outlet side, ${ }^{\circ} \mathrm{C}$.

$$
Q=m c_{p}\left(T_{\text {in }}-T_{\text {out }}\right)[\mathrm{W}]
$$

The energy performance of the heat pump was calculated in the current study with Eq. (2):

$$
E=\left[c_{p} \sum_{i=1}^{N} m_{i}\left(T_{i, \text { in }}-T_{i, \text { out }}\right) t_{i}\right] /\left(36 \cdot 10^{5}\right) \quad[\mathrm{kWh}]
$$

where: $t$ - operation time, in the study every five minutes, $\mathrm{s} ; i$-operation period; $N$ - number of cycles in the analysed period.

The COP (Coefficient of Performance) in heating period was calculated to the following equation (Eq. 3), where $Q_{B}$ - the thermal energy delivered to the buffer vessel, $Q_{H P}$ - the electricity energy consumed by the heat pump.

$$
C O P=\frac{Q_{B}}{Q_{H P}} \quad[-]
$$

\section{Experiment Result}

\subsection{Undisturbed ground temperature}

For all boreholes the undisturbed ground temperatures were measured without glycol circulation, meaning there were no heat gains from friction or pump work that influence measured values. The data acquisition system ran from October 2015 to September 2016. The monitoring system was set to record the temperatures every five minutes. The undisturbed average temperature profile is presented in Fig. 3. The first 11-12.5 m were highly influenced by seasonal atmospheric conditions. Below $12.5 \mathrm{~m}$ depth, the ground temperature did not change with seasons. The average temperature at 12.5 and $40 \mathrm{~m}$ during the measurement time was 10.2 and $8.3^{\circ} \mathrm{C}$ respectively. The geothermal gradient was about $0.07^{\circ} \mathrm{C} / \mathrm{m}$ from $12.5 \mathrm{~m}$ to $40 \mathrm{~m}$ depth. It was the constant ground temperature below $40 \mathrm{~m}$ 
depth. Deviation of temperature profile at 45 and $60 \mathrm{~m}$ of the borehole was depended on groundwater flow in this region.

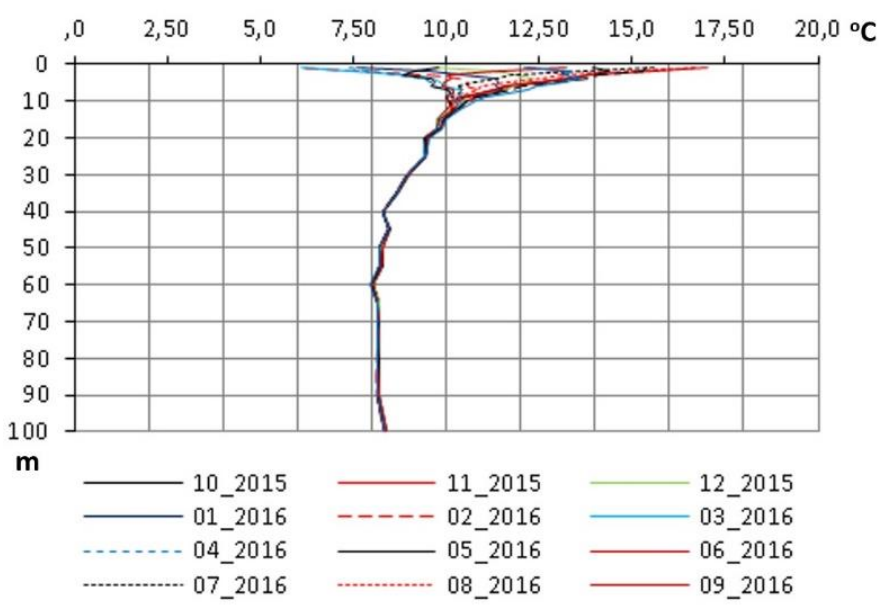

Fig. 3. Average undisturbed ground temperature profile before starting operation.

The ground temperature along the depth of the borehole for different locations were presented in Ref. $[17,18,19]$. The ground temperature along the depth of the borehole can be divided into two regions. First, where the ground temperature varies with time and the seasonal change. Second, thermostatic zone in the deeper ground $(12.5-100 \mathrm{~m})$. The zone where the ground temperature was almost constant varies from c. $8^{\circ} \mathrm{C}$ (as it can be seen in Bialystok, Fig. 3), about $11-12^{\circ} \mathrm{C}$ in Wroclaw (Poland) [17], from $10.5^{\circ} \mathrm{C}$ to $16.5^{\circ} \mathrm{C}$ in Croatia [18] and c. $20^{\circ} \mathrm{C}$ in Chongqing of China [19].

The shape of curve (Fig. 3) needs to be taken into consideration since it varies from about $10 \mathrm{~m}$ depth to about $50 \mathrm{~m}$ depth. The ground temperature at depth below the shallow zone was close to the annual average ground surface temperature. The empirical formulas [20,21] predicting the ground temperature distribution at different ground depths was loosely correlate with the measured data at this particular zone.

\subsection{GSHP system result}

The heat pump was launched on 12th January 2017 and has been operating at water volumetric flow rate of $1.515-1.551 \mathrm{~m}^{3} / \mathrm{h}$ in load side and $1.224-1.572 \mathrm{~m}^{3} / \mathrm{h}$ in source side. The temperatures in load side was respectively between $35.9-37.3^{\circ} \mathrm{C}$ at the inlet of the buffer vessel and $31.3-33.3^{\circ} \mathrm{C}$ at the outlet in each case. Definitely there were different temperatures in source side during the GSHP operating in each case (Table 2).

Table 2. The average temperature of the brine at the inlet and at the outlet in source side.

\begin{tabular}{|c|c|c|}
\hline $\begin{array}{c}\text { The average temperature of the } \\
\text { brine at the inlet of VGHE } \\
{\left[{ }^{\circ} \mathbf{C}\right]}\end{array}$ & $\begin{array}{c}\text { The average temperature of the } \\
\text { brine at the outlet of VGHE } \\
{\left[{ }^{\circ} \mathbf{C}\right]}\end{array}$ & $\begin{array}{c}\text { Total length } \\
\text { of VGHE } \\
{[\mathbf{m}]}\end{array}$ \\
\hline 1.1 & 5.1 & 100 \\
\hline 3.5 & 7.0 & 85 and 100 \\
\hline 5.1 & 8.1 & 70,85 and 100 \\
\hline-0.1 & 3.3 & 70 \\
\hline 2.0 & 6.1 & 85 \\
\hline 3.5 & 7.0 & 70 and 100 \\
\hline
\end{tabular}


Fig. 4 and 5 shows the boreholes temperature profiles during the $108 \mathrm{~h}$ operating of GSHP. Boreholes were not regenerated during this time. The temperatures of the boreholes significantly differ one from another.

Fig. 4a presents the most unfavourable profile - one VGHE with a length $70 \mathrm{~m}$. The temperature in the vicinity of VGHE dropped below $4^{\circ} \mathrm{C}$ between 20 and $70 \mathrm{~m}$ depth. Average temperature along the heat exchanger was $4,4^{\circ} \mathrm{C}$. The coefficient COP during the measurement time was 3.7 (Table 2). It is noticeable the rise of ground temperature for two heat exchangers (Fig. $\mathbf{4 b}, \mathbf{4 c}$ ). The coefficient COP was 4.2 in this case (Table 2).

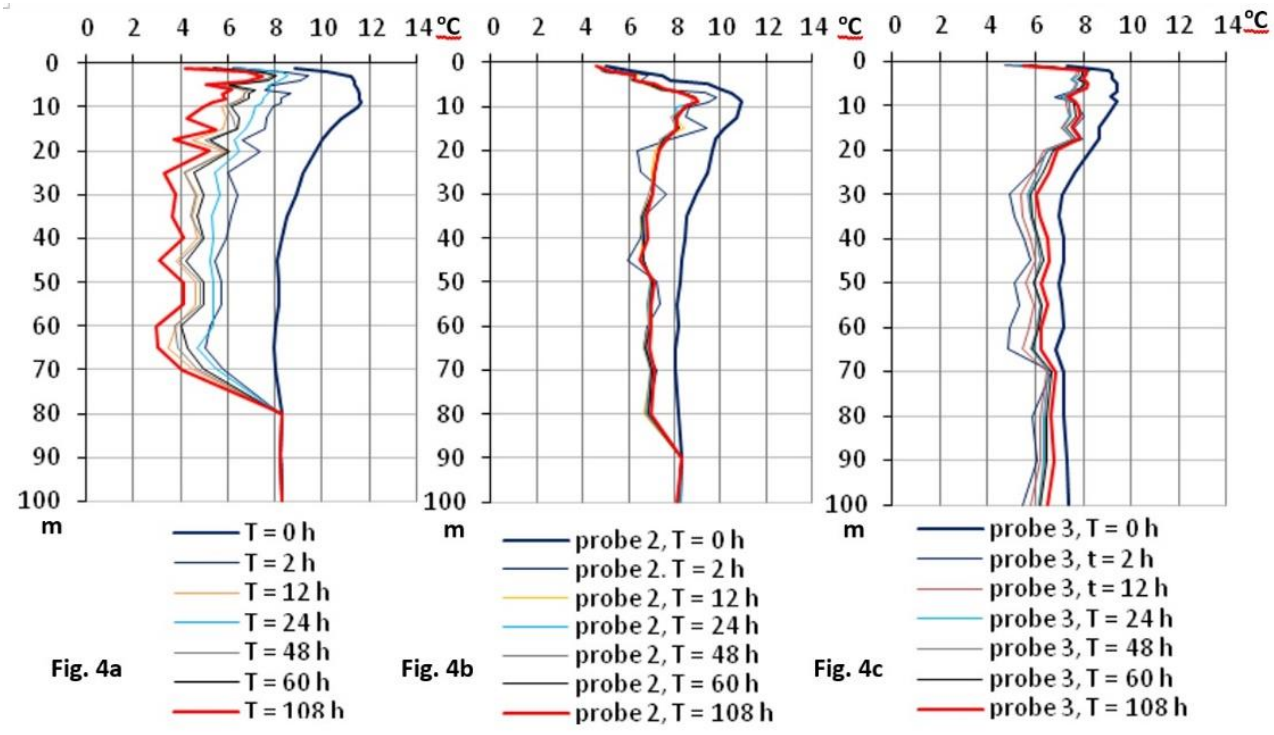

Fig. 4. Temperature profile in the vicinity VGHE for one heat exchanger $70 \mathrm{~m}$ deep (4a); temperature profile in the vicinity VGHE for two heat exchangers, borehole $2-85 \mathrm{~m}$ deep (5a) and borehole $3-100 \mathrm{~m}$ deep (5b).

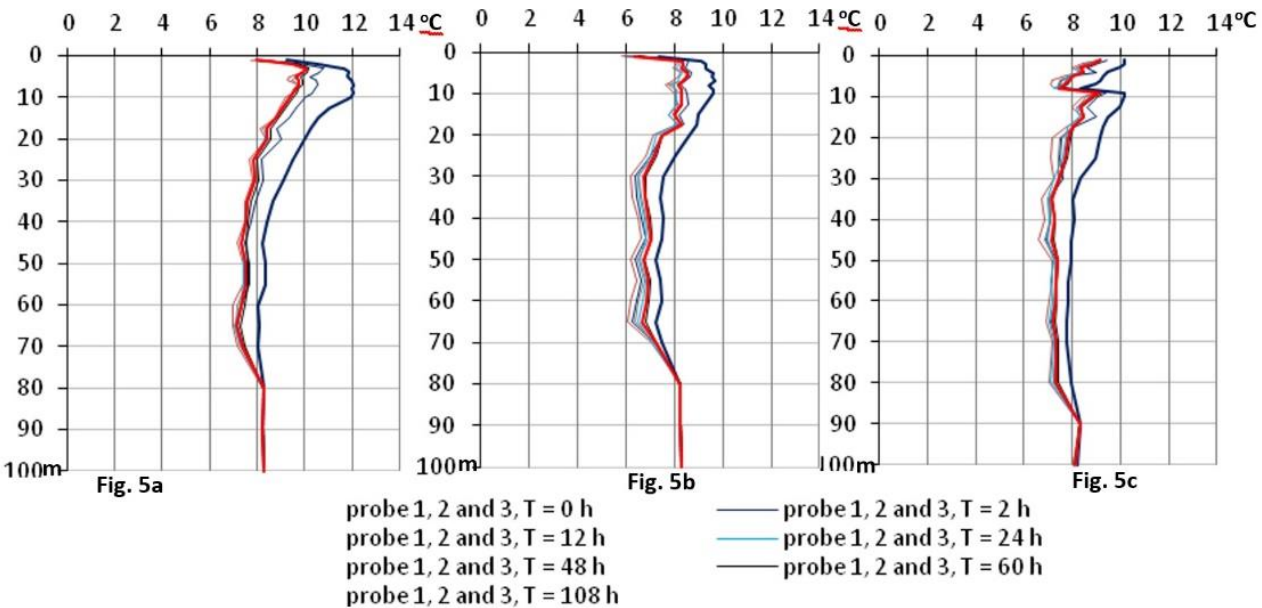

Fig. 5. Temperature profile in the vicinity VGHE for three heat exchangers $(6 a-70 m, 6 b-85 m, 6 c$ $-100 \mathrm{~m}$ deep). 
For two heat exchangers (Fig. $\mathbf{4 b}$ and $\mathbf{4 c}$ ) the average temperatures along the heat exchangers were respectively $7,3^{\circ} \mathrm{C}$ and $6,7^{\circ} \mathrm{C}$. For three VGHEs (Fig. 5) the average temperatures along the heat exchangers were $7.6^{\circ} \mathrm{C}, 7.7^{\circ} \mathrm{C}$ and $8.1^{\circ} \mathrm{C}$. There was visible increase the ground temperature in the vicinity VGHEs. The temperature was closed to undisturbed temperature profile, which provides to better efficiency of GSHP.

The graphs (Fig. 4 and 5) shows the relationship between the length of VGHEs and ground temperature profile. It affects the value of the heat pump COP (Table 3).

The average outdoor air temperature, the electrical energy consumption, the thermal energy supplied to the buffer vessel and changing the COP value during the tests were shown in Table 3.

Table 3. The heat pump COP coefficient with the different length of VGHE.

\begin{tabular}{|c|c|c|c|c|c|}
\hline Variant & $\begin{array}{c}\text { the average } \\
\text { temperature } \\
\text { of the air } \\
\text { outside } \\
{\left[{ }^{\circ} \mathrm{C}\right]}\end{array}$ & $\begin{array}{c}\begin{array}{c}\text { Electrical } \\
\text { energy } \\
\text { consumption }\end{array} \\
{[\mathbf{k W h}]}\end{array}$ & $\begin{array}{c}\text { Thermal } \\
\text { energy } \\
\text { supplied from } \\
\text { the heat pump } \\
\text { to the buffer } \\
\text { vessel } \\
{[\mathrm{kWh}]}\end{array}$ & $\begin{array}{c}\text { COP } \\
\text { during } \\
\text { the analysed } \\
\text { time } \\
{[-]}\end{array}$ & $\begin{array}{c}\text { Total length } \\
\text { of VGHE } \\
\\
{[\mathrm{m}]}\end{array}$ \\
\hline 1 & 0.8 & 42.6 & 172.4 & 4.1 & 100 \\
\hline 2 & -2.0 & 67.3 & 279.8 & 4.2 & 85 and 100 \\
\hline 3 & -2.5 & 56.8 & 236.8 & 4.2 & 70,85 and 100 \\
\hline 4 & -6.1 & 79.4 & 290.9 & 3.7 & 70 \\
\hline 5 & -6.6 & 96.1 & 363.0 & 3.8 & 85 \\
\hline 6 & -1.1 & 56.3 & 238.9 & 4.3 & 70 and 100 \\
\hline
\end{tabular}

\section{Conclusion}

The paper presents changes of ground temperature in three boreholes and the same technology with different configuration. Monitoring the temperature, mass flow, energy consumption by the heat pump and thermal energy supply to buffer vessel for selected time shows the following:

- the borehole is very sensitive on the amount of energy drawn by a heat pump,

- in case of underestimation of the heat exchanger the ground massif temperatures does not always have to be positive, then the specific heat flows transferred from the ground massif is below the design value,

- underestimation VGHE causes the COP value decreases; however increasing the length of the heat exchanger above the value recommended does not increase the COP value,

- during the experimental period, the average COP were between 3.7 and 4.3, it was below nominal value of the heat pump equals 4.7 (for comparable operation parameters); for three VGHEs COP was equal 4.2; COP for one and two VGHE were not comparable,

- design errors cause temperature in the vicinity of VGHE can drop rapidly; during the experiment to average value about $4.4^{\circ} \mathrm{C}$ for one VGHE and about $6.7-7.3^{\circ} \mathrm{C}$ for two VGHEs; results indicate that fluctuations of temperature can be relatively fast and abrupt,

- it is noticeable temperatures between the inlet and the outlet of VGHE of different length, during the operating respectively from $\left(-0.1-5.1^{\circ} \mathrm{C}\right)$ to $3.3-8.1^{\circ} \mathrm{C}$.

The study presents crucial working parameters in GSHP with VGHE for small system. The experience shows the real temperature profile along the borehole length, which is difficult to obtain for complex numerical simulations. However, the values of COP were below the nominal value 4.7 its discrepancies cannot be identified at this stage. 
The outcome is not spectacular, but it shown rapid changes in ground temperature, especially when the VGHE is underestimated. The results show for necessity regeneration of the ground.

The work requires further analysis and studies on monitoring of the heat source of the heat pump. Further research will focus on the thermal process of VGHE, solar regeneration and the storage of solar energy in the ground massif.

The study has been implemented from the resources of the S/WBiIŚ/4/14 statutory work financed by the Ministry of Science and Higher Education in Poland.

\section{References}

1. VDI 4640 Thermal use of the underground, Fundamentals, approvals, environmental aspects, Düsseldorf (2010)

2. P. J. Petit, J.P. Meyer, Energy Convers. Manag., 39, 661-669 (1998)

3. G. Florides, S. Kalogirou, Renew. Energy, 32 (15), 2461-2478 (2007)

4. H.X. Yang, P. Cui, Z.H. Fang, Appl. Energy 87, 16-27 (2010)

5. M. Li, A.C.K. Lai, Applied Energy, 151, 178-191 (2015)

6. C.K. Lee, H.N. Lam, Renew. Energy, 33 (6), 1286-1296 (2008)

7. Z. Li, M. Zheng, Appl. Therm. Eng., 29 (5-6), 920-924 (2009)

8. A. Michopoulos, N. Kyriakis, Appl. Energy, 86 (10), 2065-2070 (2009)

9. M. Aydın, A. Sisman, Applied Energy 145, 163-171 (2015)

10. B. Bouhacina, R. Saim, H. F. Oztop, Applied Thermal Engineering, 79, 153-162 (2015)

11. ASHRAE. ASHRAE handbook: HVAC applications. Atlanta: ASHRAE (2011)

12. H. Fujii, et al., Geothermics, 38, 399-406 (2009)

13. J. Raymond, R. Therrien, L. Gosselin, Geothermics, 40, 69-78 (2011)

14. X. Yu, Y. Zhang, N. Deng, H Ma, S. Dong, Applied Thermal Engineering 93, 678-682 (2016).

15. D. Marcotte, P. Pasquier, Renew. Energy 33, 2407-2415 (2008)

16. R. Treviño, J. Contreras, D. Fresno, Appl. Therm. Eng. 82, 39-47 (2015)

17. N. Fidorów, M. Szulgowska-Zgrzywa, Applied Thermal Engineering 82, 237-245 (2015)

18. V. Soldo, L. Boban, S. Borović, Renewable Energy 99, 1202-1212 (2016)

19. S. Zhou, W. Cui, J. Tao, Q. Peng, Applied Thermal Engineering 101, 173-182 (2016)

20. T. Kasuda, P.R. Archenbach, ASHRAE Trans. 71, Part 1 (1965)

21. M. Badache, P. Eslami-Nejad, M. Ouzzane, Z. Aidoun, L. Lamarche, Renewable Energy 85, 436-444 (2016) 